\title{
ASPECTOS DO REALISMO-NATURALISMO NO BRASIL
}

Sílvio Romero, no opúsculo $O$ naturalismo em literatura, publicado em 1882, um ano depois de $O$ mulato de Aluísio Azevedo, reivindica para si a glória de ter sido o introdutor das idéias naturalistas no Brasil. Na "Advertência" daquele trabalho, principia dizendo que por volta de 1869 êle divulgava no Brasil umas tantas idéias que, catorze anos mais tarde, ainda eram consideradas como novidade. Divulgou-as, entre 1869-1876, na Crença, Movimento, Americano, Trabalho, Jornal do Recife, Correio Pernambucano e outros jornais. E' de 1869 , sua monografia $A$ poesia contemporânea e sua visão naturalista, ensaio que escreveu, diz êle, quando Emílio Zola the era desconhecido, bem como ao público brasileiro.

De fato, Sílvio Romero divulgou, juntamente com Tobias Barreto, muita coisa de novo: o naturalismo de Darwin, base do evolucionismo de Spencer, a sociologia de Taine, ou melhor, seu método crítico-sociológico e, como expressão do progresso científico da segunda metade do século XIX, pretendeu entre nós o cultivo da poesia científica.

Essa divulgação contribuiu para criar no Brasil o clima propício à aceitação do realismo e do naturalismo, pois que ambos existiram em grande parte como conseqüência do advento do positivismo, do evolucionismo, das idéias sociológicas e críticas de Taine e, em suma, do progresso científico do século XIX. Mas é igualmente certo que Sílvio Romero não divulgou pròpriamente a teoria estética do realismo ou do naturalismo.

A divulgação da doutrina, podemos dizer que se fêz através do conhecimento direto dos autores europeus. E' o próprio Sílvio Romero, embora em tom de polêmica e de desabafo, quem nos informa que o sinal de alarma da existência da literatura realista ou naturalista, nos foi dado na Revista Brasileira por Machado de Assis e Herculano Bandeira. Realmente, o estudo das novas correntes, que maior repercussão teve em nossos meios literários, foi a crítica que sôbre os romances $O$ crime do Padre Amaro e $O$ primo Basílio, escreveu Machado de Assis, em 1878. Esclarecia o público brasileiro, entusiasmado com aquêles dois romances, sôbre algumas particularidades fundamentais da escola que êle mesmo já conhecia não só através de suas realizações, mas também, pelo que se depreende da crí- 
tica que escreveu, através das considerações teórıcas do mestre do naturalismo.

A crítica de Machado de Assis provocou celeuma e avisou definitivamente o público brasileiro da existência das novas tendências. Pouco depois chegou até nós $O$ romance experimental de Zola. E, em 1881, surgiu $O$ mulato de Aluísio Azevedo, romance que foi ao mesmo tempo o primeiro exemplar de obra realista-naturalista no Brasil conscientemente filiada à nova tendência e refletidora de influências de mestres franceses e particularmente de $\mathbf{E}_{\text {ça de Queiroz. }}$

Enquadrados dentro da segunda época da érà nacional ou autonômica de nossa história literária, que limitamos de 1869 — início da reação crítica e filosófica, anti-romântica, encabeçada por Sílvio Romero e Tobias Barreto, até 1902 - ano da publicação da $H$ istótia da literatura brasileira, (2a. edição) de Ślvio Romero, de Os sertões de Euclides da Cunha, do Canaã de Graça Aranha, apontamos como principais representantes do romance denominado realista ou naturalista, os seguintes nomes, acompanhados, respectivamente, de suas obras de estréia: 1872 ;

1. - J. M. Machado de Assis (1839-1908) - Ressurreição,

2. - Júlio César Ribeiro (1845-1890) - O Padre Belchior de Pontes, 1876-1877;

3. - Aluísio T. B. G. de Azevedo (1857-1913) - Uma lágrima de mulher, 1880;

4. - H. M. Inglês de Souza (1853-1918) - História de um pescador 1876;

5. - Rodolfo M. Teófilo (1853-1953) - A fome, 1890;

6. - Adolfo F. Caminha (1867-1897) - A normalista, 1892;

7. - H. Coelho Neto (1864-1934) - A Capital Federal, 1893 (Rapsódias, 1891);

8. - Domingos Olímpio Braga Cavalcanti (1850-1906) Luzia-Homem, 1903.

Consideramos como precursor do modernismo ou como romancistas de transição: Raul d'Avila Pompéia (1863-1895) - $O$ Ateneu, 1888; J. P. da Graça Aranha (1868-1931) - Canaã, 1902; e A. H. de Lima Barreto (1881-1922) - Recordaçóes do escrivão Isaias Caminha, 1909. Porque os consideramos precursores, seria matéria para outro ensaio, razão pela qual apenas lhes fazemos referência no presente.

Por outro lado, deixamos de fazer o devido estudo da obra de Coelho Neto, sobretudo por causa de sua variedade e de seu ecletismo. Ao demais, o nosso verdadeiro objetivo é mostrar os principais aspectos e sentido das realizações realistas e naturalistas entre nós, pelo que nos detemos apenas nos seus representantes mais significativos. 


\section{I. - Prefácio a Machado de Assis}

1. - Ao estudarmos os escritores realistas-naturalistas, colocamos Machado de Assis em primeiro lugar por uma questão puramente cronológica, pois, a rigor, o primeiro romance filiado ao realismo é $O$ mulato de Aluísio Azevedo. De resto, somos da opinião de que Machado de Assis não pode ser classificado dentro de rígido conceito de escola literária, seja esta romântica, realista ou naturalista. Sua atitude, em face das escolas literárias, já o dissemos em outra oportunidade: é sem dúvida alguma a do escritor de formação segura, coerente, senhor dos seus processos e possuidor de uma estética bem definida e orientada pelo bom senso. Tanto mais que a crítica muitas vêzes disse que Machado de Assis é "caso único" na literatura brasileira, o que não tem significado, a não ser se tomarmos esta expressão como indicadora da superioridade - nacionalismo e universalismo - do escritor.

Cremos que, ao apreciarmos os romances de Machado de Assis, levando em consideração seus estudos, constante leitura dos escritores portuguêses, brasileiros e estrangeiros, desde os clássicos, o que devemos ver inicialmente é a evolução técnica ou formal da obra que êle escreveu, ao lado da evolução das idéias, sem dúvida ligadas às referidas leituras e à sua experiência humana. Impõe-se, portanto, a leitura da obra do romancista - o que aliás não constitue novidade - na ordem cronológica da elaboração: de Ressurreição a Memorial de Aires.

A crítica costuma distribuíla em duas fases: a primeira, constituída dos romances Ressurreição, $A$ mão e a luva, Helena, Yayá Garcia; a segunda, das obras Memórias póstumas de Braz Cubas, Quincas Borba, Dom Casmurro, Esaú e Jacob, Memorial de Aires, não considerando aqui os contos que obedecem à mesma classificação.

Se aceitamos a divisão, achamos, contudo, que é discutivel a classificação que de ordinário se pretende, dos primeiros romances como românticos, em oposição aos da segunda fase, considerados realistas. Admitimos a divisão em duas fases, mas apreciamos a primeira como sendo de experiência e a segunda, como de afirmação.

O próprio Machado de Assis, em prefácio a reedições de romances da primeira fase, já depois de haver publicado livros da seguinte, escreveu que o seu verdadeiro desềjo era refundir essas reediçōes, mas resolveu mantê-las da mesma forma como foram publicadas pela primeira vez, porque as considerava simples exercícios literários do início de sua carreira de escritor.

Realmente, a impressão que logo temos ao ler os romances da primeira fase, é a de que êles são livros elaborados por escritor que se exercita, que procura técnica e definição de estilo, enfim, de escritor que experimenta os recursos de seu talento e da experiência já adquirida e de ambos dá aviso ao público. A descoberta de técni- 
ca segura e própria e a definição de estilo só aparecem em tôda a sua plenitude nos romances de Memórias póstumas de Braz Cubas em diante.

Nestas condições, um dos pontos de partida da crítica, ao estudar o romancista, é a observação da evolução técnica ou formal ou expressional de sua obra do primeiro para o segundo grupo. $\mathbf{E}$ essa evolução crescente é visível desde a técnica do diálogo, apresentação e desenvolvimento do argumento e dos temas, até a completa definição do drama e caracterização dos personagens que, nos romances da primeira fase, ao contrário dos da segunda, precede à definição do drama, à ação ou ao comportamento dos mesmos personagens. E' importante tambẻm observar, nos primeiros romances, como a ação é limitada a poucos personagens, o que quase đá a êstes livros a feição de novela. Mas tal limitação é o produto da preocupação dominante em Machado de Assis de eliminar todos os elementos acessórios, fortuitos ou acidentais que não sejam realmente significativos. Assim, progressivamente da primeira para a segunda fase, Machado de Assis atinge o poder incomparável, na literatura brasileira, da expressão exata, direta, objetiva, irredutível a ponto de tornar-se excessivamente econômico, quer na descrição, tão pouco freqüente nos seus romances, quer na narração, na dissertação ou no diálogo que são as espécies de composição predominantes no gênero.

2. - Reafirmamos que a verdadeira divisão da obra de Machado de Assis deve obedecer ao critério de observação de sua evolução técnica e temática. Ele não pertence nem se filiou a qualquer escola, apesar de ter conhecido de perto o romantismo, o realismonaturalismo, o parnasianismo e de haver estudado os clássicos. $\mathrm{E}$ se assim aconteceu, não foi por indiferentismo ou incapacidade, mas porque soube evitar os excessos, fugir ao sectarismo, ao espírito de seita que tanto condenou, e porque soube aproveitar e assimilar de tôdas elas aquilo que a arte apresenta de permanente e universal e que é o fio que dá unidade a tôdas as tendências, fazendo sempre contemporâneos Homero, Petrarca, Camões, Shakespeare, Molière.

Não resta dúvida que, na primeira fase, observamos reminiscências românticas notadamente na apresentação dos temas e na fixação da vida sentimental dos personagens, coisas que se equivalem. Mas tais reminiscências são consciente ou intencionalmente acentuadas, dado o seu propósito de moderação e coerência, não só porque Machado de Assis condenou os excessos do romantismo e por extensão os das demais escolas - como também porque, desde a primeira página que escreveu, foi guiado pela sua tendência fundamental: o psicologismo, a penetração no mundo íntimo dos personagens, atitude que o romantismo ignorou ou com a qual não se preocupou, desde que o mundo por êle fixado foi essencialmente o sentimental, mas aquêle que se traduz apenas pelos atos exteriores - de um comportamento com base, predominantemente, nas paixōes 
e nos sentimentos amorosos sujeitos ao ódio, à vingança, à renúncia, à abnegação, numa verdadeira luta de virtudes e de valores morais, em que triunfa o bem contra o mal.

Ora, Machado de Assis nos romances como Ressurreição, $A$ mão e a luva, Helena e Yayá Garcia, preocupa-se mais com o introspectivo, com as causas íntimas e secretas formadoras de paixões, determinadoras de comportamento, do que pròpriamente com os efeitos manifestos ou com a visão exterior da vida sentimental. Ao demais, nestes romances êle já ultrapassa um dos limites tão conhecidos da ficção romântica e atinge a vida post-conjugal; mas, ultrapassando tais limites, êle não segue a indiscrição realista. Desde a primeira fase, revelou a atitude dominante nos romances posteriores: o equilíbrio e a discrição no estudo do comportamento humano, livre de influências de teorias e de modas literárias, as quais reduzem a função do romancista à moralização e à doutrinação. $\mathbf{E}$ foi também em consequiência desta atitude - e porque sempre se preocupou em fixar tão sòmente a verdade moral - que Machado de Assis desprezou, tanto na primeira como na segunda fase, tudo o que lhe pareceu vulgarmente acessório, fortuito ou acidental, quer se relacionasse com o ambiente ou com o drama, quer com a ação ou com o comportamento dos personagens, conforme já salientamos. $\mathrm{Na}$ primeira fase, êle principia a atingir o que conseguiu plenamente na segunda: o intelectualismo. Se aparecem elementos sociais, elementos ligados à descrição de ambientes ou de paisagens à maneira romântica ou à naturalista, nos primeiros como nos últimos romances, foi apenas porque o escritor nunca pôde evitar totalmente as influências dominantes. Sabemos como a descrição e a informação de caráter social foram limitadas nos livros de Machado de Assis ao estrita e rigorosamente necessário, o que nem todos os críticos têm sabido compreender. Insistimos: realmente houve no romancista a preocupação bem consciente de eliminar o acessório e o temporário que cedem lugar às generalizações e à apreensão dos fatos e coisas essenciais, que tendem para o universalismo.

Por tudo isto se justifica a procura de posição literária na primeira fase, posição definida completamente na segunda com grande superioridade e originalidade. Ressaltamos, embora ràpidamente e sem a necessária exemplificação, o fato de os aspectos técnicos dos primeiros desenvolverem-se e aperfeiçoarem-se nos romances posteriores. Quanto à temática, verifica-se um espantoso progresso em profundidade, o que reflete uma experiência intensa e constante do romancista, produto tanto da observação da natureza humana quanto de leituras bem assimiladas. Tornou-se Machado de Assis, no que diz respeito às influências recebidas, um excepcional recriador e ao mesmo tempo espirito original de criador.

Costuma-se com certa insistência interpretar a obra, ou mais especìficamente, a temática do romancista à luz, digamos, da psicanálise, pretendendo-se que seus livros - pelo menos os principais 
- estão em íntima relação com a origem, constituição e doença, da epilepsia à timidez. Como já dissemos anteriormente e também já o escrevemos em outro trabalho, somos de opinião contrária e achamos que a obra do escritor deve ser vista independentemente do homem, mas à luz da formação do escritor, das influências que êste recebeu, de suas idéias estéticas e filosofia de vida. Condenando a atitude dominante de alguns críticos e em parte servindo para confirmar a orientação que defendemos, citamos um artigo que lemos do crítico português João Gaspar Simões que vai além dos nossos limites e que sugere (serve-se de idéias de um crítico francês) para a melhor compreensão da obra do romancista, a mesma orientação que Aristóteles dava à interpretação da tragédia grega, fundamentado no princípio da catharsis. Vê-se por aí que tôda a obra de Machado de Assis realiza sempre um processo de purificação das paixões e dos vícios humanos. Acrescente-se a esta interpretação a influência do humorismo inglês, humorismo que coloca o romancista em posição neutra em face dos valores morais; daí sem dúvida resulta outra atitude fundamental de Machado de Assis que procurou, livre de qualquer constrangimento, revelar certos aspectos da natureza humana, friamente, porém com penetrante observação psicológica e sem deixar de transparecer seu próprio sentimento de humanidade, tolerância e compreensão.

\section{II. - Aluísio Azevedo}

1. - A crítica em geral admite que o verdadeiro inaugurador das novas tendências realistas-naturalistas no Brasil foi Aluísio Azevedo. Afirmou-as em 1881, quando foi publicado $O$ mulato. Mas o seu primeiro romance - Uma lágrima de mulher - foi predominantemente romântico. Escreveu-o no Maranhão, em 1879, quando para aí regressou, depois de curta permanência no Rio de Janeiro.

Vocação artística acentuada, Aluísio Azevedo já devia então conhecer as novas doutrinas literárias através da divulgação da crítica e da circulação entre nós de alguns romances estrangeiros. Mesmo assim, estreou com um romance considerado romântico. $E$ o fato pode ser justificado primeiramente pela formação do escritor: jovem, ainda adolescente, havia sido criado em clima romântico; o realismo-naturalismo debatido entre nós em fins da década de 1870 , não contava com um realizador brasileiro de vulto e ao mesmo tempo de repercussão, de forma que o primeiro livro de Alúsio Azevedo estava fadado a ser senão inteiramente, pelo menos predominantemente romântico. Considere-se, ao demais, que êste jovem tinha a favor da preferência romântica a idade psicológica.

Pouco maais ou menos dois anos depois, lançou seu primeiro romance de sucesso, $O$ mulato, que, como vimos, é considerado marco inicial do realismo-naturalismo no Brasil. Note-se, porém, que é romance caracteristicamente de transição, razão pela qual, dentro da 
história literária, é obra iniciadora. Dela não se pode exigir a realização de todos os fundamentos da nova doutrina, pelo menos equilibradamente.

De restio, não é possível uma rigorosa divisão da obra de Aluísio Azevedo em romântica e realista-naturalista. E o motivo que o impede, é não só decorrente da formação do escritor como também de ordem estética. Explica-se então o fato de a obra de Aluísio Azevedo, de $O$ mulato em diante, manifestar freqüentemente reminiscências românticas. Para êsse aparente desequilíbrio, bem como para os altos e baixos de tudo que êle escreveu, há outra justificativa da máxima importância, que se resume nas circunstâncias em que foram escritos quase todos os seus romances, isto é, o freqüente choque da realidade com $o$ ideal de escritor.

Esclareçamos. Depois do sucesso de $O$ mulato, Aluísio Azevedo transferiu-se definitivamente para a Côrte. Coelho Neto, conterrâneo e íntimo amigo do romancista, a êle se refere em mais de uma passagem de Fogo fátuo e de $A$ conquista; afirma que Aluísio Azevedo desejava ser exclusivamente um profissional da arte, viver para a literatura e ao mesmo tempo da literatura. $\mathrm{O}$ meio acanhado, a falta de público preparado para a leitura, a reduzida tiragem e circulação do livro, não permitiam, de modo geral, que o romancista pudesse se entregar inteiramente à atividade literária e dela viver com decência e dignidade. Em tais condições e pela necessidade de subsistência, Aluísio Azevedo teve de sacrificar seu ideal de romancista e viu-se obrigado a satisfazer as exigências de um público na maioria sem gôsto e viciado: o leitor dos "folhetins" dos jornais da época, muito parecido com o ouvinte das novelas radiofônicas dos nossos dias. Naquela época, como ainda hoje entre os ouvintes de novelas radiofônicas, o gôsto do leitor indicado só possibilitava um sucesso: o de dramalhões ou de romances ultra-românticos, de reduzido valor literário. E' por isto que encontramos no conjunto da obra de Aluísio Azevedo alguns romances que são verdadeiros dramalhões, exagerados em suas tendências, muitas vêzes mistura de morbidez romântica com atitudes realistas falsas, moral e psicològicamente. Constitui excelente exemplo $A$ mortalha de Alzira.

Ficam indicadas, a nosso ver, as razões fundamentais, pelas quais Aluísio Azevedo foi levado a sacrificar o seu ideal de romancista. E sem dúvida estava possuído de um ideal louvável. Conta-nos o autor de Mano, que Alúisio Azevedo, dominado pela influência de Zola, planejou igualmente uma obra seriada, que devia ser um estudo dos aspectos mais característicos do viver brasileiro da sociedade do Império. $\mathbf{E}$ que, para realizar a obra, tomou atitudes de verdadeiro naturalista, procurando observar minuciosamente $o$ ambiente, realizar a colheita pessoal e diretamente dos fatos observados, da mesma forma que apreender os tipos característicos e representativos das camadas sociais estudadas : 
O que seria essa realização, nós pcdemos avaliar através de $O$ Cortiço cujo esquema, assunto e tese estavam enquadrados no plano geral da obra cíclica. Ao mesmo tempo, a prova de que as circunstâncias prejudicaram o escritor, dá-nos a leitura de $O$ esqueleto que, publicado inicialmente em folhetins de jornais, descambou para o plano caricaturesco. E é sabido, pelas informações de Coelho Neto, que $O$ esqueleto também fazia parte daquele plano de romance seriado.

Todos os fatos indicados, acrescentados da pouca cultura do romancista e do modo pelo qual êle compreendeu o naturalismo, determinaram, em última análise, as reminiscências românticas e a feição mais realista do que naturalista de sua obra. Podemos definir Aluísio Azevedo como um romancista predominantemente social, de acôrdo com o realismo-naturalismo, mas com visíveis reminiscências românticas.

2. - Do conjunto da obra de Aluísio Azevedo, a crítica consagrou quatro romances, aos quais o público também deu particular preferência: $O$ mulato, Casa de pensão, $O$ Coruja e $O$ cortiço. Realmente são quatro romances destacados da atividade literária do escritor e com os quais podemos comprovar as observações que fizemos antes.

O mulató é, em verdade, o romance de estréia de Aluísio Azevedo. Foi escrito em plena mocidade, quando o autor, procurando um caminho para a sua arte, resolveu libertar-se das influências românticas quer literárias quer intrínsecas à sua idade psicológica.

Tendo estado na Côrte e conhecido de perto o rumor das novas tendências literárias através da crítica e da leitura de romances realistas-naturalistas, como por exemplo os de Eça de Queiroz, Aluísio Azevedo quis escrever $O$ mulato de acôrdo com a novidade literária que se propagava. De fato assim o fêz, mas em muitos momentos procedeu, cremos que involuntàriamente, como um verdadeiro escritor de transição. Sem dúvida, porque $O$ mulato é obra iniciadora de novas tendências, deve, antes de tudo, ser apreciada pelas suas características de transição.

A tese essencial do romance é, já em plano bem social, o problema da marginalidade do mulato na sociedade brasileira, na sociedade provinciana do princípio do Segundo Império, em que a herança colonial, feita não só de preconceitos de côr mas também da ostensiva superioridade do branco representado pelos portuguêses (estamos em São Luiz do Maranhão) era ainda bem viva.

Lembramos, em primeiro lugar, que o argumento ou o drama, em apôio da tese do romance, encontra antecedentes na literatura brasileira. Dêstes, o mais importante e próximo é o romance $A$ escrava Isaura de Bernardo Guimarães. Repetimos que a tese, em ambos os romances, é a mesma; apenas o seu tratamento é diferente: em Aluísio Azevedo está revestida de grandes preocupações realistas, em Bernardo Guimarães é perfeitamente romântica, além de ou. 
tros aspectos importantes, que pássaremos a ressaltar, ao lado dos pontos de contacto.

Bernardo Guimarães tratóu däs relações do escravo com o branco no seu ambiente mais próprio, isto é, num centro agrícola. Mas apresentou-nôs o escravo mestiço e cria de família, o qual, em convívio íntimo com a família de tipo patriarcal, comumente recebia, diretamente ou pelo exemplo, educação aproximadà à dos fithos de seus senhores. Só por isto, o escravo mestiço afastáva-se do elemento pròpriamente escravo, habitante da senzala, mas em contrapartida não podia chegar ao elemento branco, desde que se repudiava a sua plena integração no seio da sociedade. Daí o problema da marginalidade do escravo-mestiço, ou simplesmente do mestiço, e o papel dramático que o escritor romântico the atribuiu.

Ao mestiço, além das relações domésticas e de outrāas puràmente convencionais, só era possivel um outro meio de contacto com o branco: as relações sexuais ilícitas, o que entrava em choque com a formação moral recebida ou com o seu ideal sentimental. E assim mesmo sob a forma de dilema: ou aceitava essas relações ilícitas (às vêzes as aceitava de qualquer forma) ou fechava-se no seu círculo, porque the era repugnante descer ao elemento inferior, negativo de sua origem - o preto.

Bernardo Guimarães deu ao problema uma solução perfeitamente romântica, aproveitando a oportunidade da campanha abolicionista. Em oposição ao escravagista sensual, libidinoso, colocou o abolicionista sentimental e sem preconceito, mas ambos representantes da família de tipo patriarcal. Vence o abolicionista que se consorcia religiosa e legalmente com a mulata. Fica indicada em têrmos bem claros a solução dada ao problema e, ao mesmo tempo, ao drama do mestiço, conforme estabelecemos há pouco: o mulato, possuidor de qualidades semelhantes às do branco, devia ser aceito legítima - e o que é mais importante - humanamente no seio da sociedade.

Aluísio Azevedo, em $O$ mulato, não desenvolve outro drama senão o proposto por Bernardo Guimarães, e sugere a mesma tese. Apenas, como ressaltamos, com diferença de tratamento - ambiente e atitude estética - o que dá ao seu romance um sentido social mais avançado, mas não the exclui a existência, por outro lado, de intimos pontos de contacto com o de Bernardo Guimarães.

Freqüentemente lemos que o romance de Aluísio Azevedo traduz 0 ressentimento do autor para com a província natal, porque esta the negou o apôio necessário à realização de estudos almejados. Temos a impressão de que se trata de uma alegação de pouca importância literária, que, quando muito, determinou a atitude do romancista ao fazer a caricatura de sociedade de São Luiz do Maranhão, expondo-a em todo o seu ridículo de falsos preconceitos. Sem dúvida o motivo mais próximo da elaboração do romance foi o cli.. ma criado pela campanha abolicionista, além do exemplo dado por 
Bernardo Guimarães e da sugestão deixada pelo drama romântico, pessoal, de Gonçalves Dias.

O'ambiente em que se desenrola a ação de $O$ mulato é São Luiz do Maranhão, um dos principais centros do Segundo Império, o que se opõe fundamentalmente ao ambiente de $A$ escrava Isaura, embora Bernardo Guimarães chegue a conduzir a heroína, quando foge à sanha sensual do seu senhor, até Recife.

Outra diferença fundamental está nos têrmos iniciais em que Aluísio Azevedo coloca o drama do romance. $O$ mestiço que aparece em $O$ mulato, desconhece por longos anos a sua origem, apesar de suspeitá-la em determinado momento, para conhecê-la definitivamente em outro; recebeu de seu tutor, depois da morte do pai, fina e completa educação e instrução, mas no estrangeiro, longe, portanto, de seu meio de origem. Quando para aí regressou, já era um espírito formado, sem quaisquer reminiscências provincianas, tanto que seu propósito era o de se fixar na Côrte, depois de liquidados os negócios que o levaram de volta a São Luiz. Em tais condições, foi como que jogado em um meio do qual sofreu durante algum tempo, sem atinar com as razões fundamentais e às vêzes sem percebê-las, uma reação muda e intensa.

E' pelos motivos indicados que achamos que o romance peca pela base: pretendendo indubitàvelmente focalizar o drama do mulato - e do ponto de vista realista - não soube encará-lo em condições que verdadeiramente corespondessem à realidade e à verdade moral. E' inquestionável que o mestiço de $O$ mulato se tor- nou uma figura estranha ao meio de origem, motivo pelo qual näo pode traduzir com verossimilhança o drama do mesmo mestiço da escravidão. Além do mais, talvez seja esta a principal razão pela qual o mulato de Aluísio Azevedo é uma figura mais romântica e falsamente romântica - do que à escrava Isaura criada por Bernardo Guimarães. Raimundo é figura idealizada em flagrante contraste com o ambiente provinciano pintado com tintas realistas, da mesma forma que; no drama do qual a sua origem mestiça é a razão única, com os outros personagens que o secundam.

Apesar das restrições que acabamos de fazer, $O$ mulato apresenta mais interêsse social do que $A$ escrava Isaura e é tècnicamente incomparável a êste último. E, não obstante muitas reminiscências românticas fàcilmente identificáveis, é predominantementte realista, inaugurador das novas tendências na ficção brasileira com o sucesso que a critica justamente the atribuiu. As preocupações realistas de Aluísio Azevedo podem ser observadas desde o propósito de querer fixar um tipo histérico de mulher, de pretender considerar científicamente as relações sexuais e esmiuçar a vida íntima, até a vitória das "fôrças do mal" - usando-se aqui expressão de gôsto romântico além da acomodação burguesa que encobre crimes e manchas morais, possibilitando o desfêcho do romance, em que vemos a prima de Raimundo, numa situação de arranjo, espôsa daquele que the era 
repugnante e que era o rival e assassino do mesmo Raimundo que foi o seu exaltado primeiro amor.

Lembramos a propósito de observações anteriores que, apesar da situação criada, Aluísio Azevedo sugere como solução única para o problema do mulato, naturalmente educado e instruído, - o consórcio com o branco, da mesma forma que o vemos em $\boldsymbol{A}$ escrava Isauta.

3. - Casa de pensão é o segundo romance consagrado de Aluísio Azevedo e com êle seu autor se aproxima consideràvelmente, não da teoria pròpriamente dita, mas de certos processos do naturalismo. Todos sabem que o argumento do romance foi sugerido por um episódio autêntico, um crime passional perpetrado por um estudante. Aluísio Azevedo aproveitou-se dos noticiários de jornais e da repercussão do fato na opinião pública, para transformá-lo em matéria de romance. $O$ processo foi simples: seguiu o conselho de Zola, dado a um jovem romancista que lhe pediu orientação - faça reportagem. Mas, acrescentaria Zola, estude o fato e o indivíduo à luz da influência do meio, da educação e da herança biológica, trabalhando todo $e$ material colhido com a minúcia, a precisão e a objetividade da análise científica. $E_{m}$ verdade, porém, o que fêz Aluísio Azevedo foi estudar socialmente a causa ou o móvel do crime.

O romancista transportou da província do Maranhão para o Rio de Janeiro, quer dizer, para a Côrte, um estudante. $O$ deslocamento provcicou uma situação tôda especial, em virtude, primeiro. da educação recebida pelo estudante - educação doméstica; ao lado dela, o método de instrução, ambos, na indicação do romantcista, recalcadores de expansões naturais e, como valores provincianos, opostos aos da Côrte. Assim, vemos em segundo lugar a disparidade entre a vida provinciana e a da Côrte. Notamos que êste contraste atuou na vida do estudante principalmente através dos vícios, dos costumes relaxados, da relativa facilidade de aventuras e também da facilidade com que o inexperiente provinciano caía nas mãos de aventureiros inescrupulosos. Pelo menos assim devíamos concluir, se não nos ressaltasse à vista a situação de liberdade em que o estudante se encontra na Côrte e certa incapacidade de reação que tão freqüentemente Aluísio Azevedo atribuiu aos seus personagens, fatos que tornam as observações anteriores se:undárias.

Em todo caso, preparado o ambiente, o jovem estudante que veio da província para a Côrte, procuraria, por um impulso natural, uma completa libertação dos freios da educação anteriormente recebida. $\mathbf{E}$, entregando-se às aventuras, às conquistas amorosas e aos vícios, perdeu logo qualquer escrúpulo, virtude que, a rigor, êle não pcssuia. E fàcilmente, quase como um títere, foi conduzido à tragédia final - o crime passional, que empresta àquêle drania meio burlesco as próprias proporções do trágico. 
Não podemos dizer que haja no romance elementos psicológicos; tudo é estudado à luz dos fatos externos, num plano superficialmente social, semelhante às reportagens romanceadas e um tanto melodramáticas. Por isto, Aluísio Azevedo deu ou pretendeu dar grande importância ao meio e, com o grande conhecimento que teve, produto de experiências pessoais, das pensões burguesas do Rio de Janeiro de sua época, as quais já havia estudado em página de crônica, apontando-as como umá das mais rendosas aventuras de então, procurou fixar no romance aquêle citado tipo de morada coletiva, com o que realiza um documentário social de relativo interêsse.

Como ficou visto pelo que dissemos, a tese do romance é, em síntese, o desajustamento do estudante que veio da província para a Côrte, admitindo-se a desigualdade de nível social, moral e intelectual entre os dois centros indicados. Em valorização da obra, Aluísio Azevedo revela excelentes qualidades de romancista social, com acentuada tendência para a focalização dos movimentos de massa, ou de pequenas coletividades, é melhor dizer grupos, conforme já se tem observado.

Em $O$ Coruja, o romancista continua com a preocupação de fazer romance naturalista, desejando estudar o tipo político e ao mesmo tempo murdano da época, pôsto em posição de contraste com o tipo idealista, sincero, expressão de real valor moral e intelectual. Contudo, o que êle faz, tomando a expressão de Victor Hugo, é, na criação do Coruja, a aproximação do sublime ao grotesco, estabelecendo um constraste de acentuado gôsto romântico.

De fato, em $O$ Coruja, se há realismo de cenas, de situações, de descrições de ambiente, predomina, contudo, a ação dramática característicamente romântica. $\mathrm{E}$ é quase patético, quando não descamba para o caricaturesco.

Para uma apreciação final, escolhemos o melhor dos romances de Aluísio Azevedo, tanto pela técnica de construção quanto pela temática e tese - $O$ cortiço, aliás escrito antes de $O$ Coruja. Reafirma-se seguramente em $O$ cortiço, a tendência social, de romancista fixador de movimentos de massa, que o foi Aluísio Azevedo.

$O$ romance é o estudo de um fenômeno social característico da época, mas não exclusivo, pois ainda hoje é bem vivo - o cortiço, tipo de morada coletiva popular. A obra ainda realiza um outro importante estudo que, na fixação das relações entre a plebe e a burguesia, consiste na crítica ao processo de valorização do homem na sociedade brasileira. O que êle mostra, em suma, é a nossa sociedade, sem valores e tradições definidos, recebendo, exatamente no momento em que procura definí-los, influências externas às vêzes perniciosas, porque trazidas por elementos caracterìsticamente aventureiros. Justifica-se em parte o processo de valorização do homem em tal sociedade, feito em plano material, isto é, exclusivamente econômico. Um aventureiro inescrupuloso, ao mesmo tempo inteligen- 
te, pode sair de ambiente corrompido, ou degenerado, para as camadas burguesas e mesmo pseudo-aristocráticas, representativas da nata da sociadede. O passaporte é o dinheiro. João Romão é o símbolo dessa valorização do homem e igualmente do imigrante de procedência ou de situação obscura.

Podemos dizer que $O$ cortiço é o único dos livros de Aluisio Azevedo, que se aproxima do naturalismo de modo mais convincente que os outros que êle escreveu; não chega, porém, a ser uma obra naturalista com aplicação do método, dos processos da doutrina, segundo Zola, o que nos leva a concluir que o romancista não se capacitou suficientemente, para executá-la. Faltou-lhe o equilíbrio necessário à focalização das relações dos personagens com o meio e cientificamente é falho no estudo das influências da educação e da herança biológica no comportamento humano. Relacionando as duas atitudes fundamentais do naturalismo, notamos também a falta de equilíbrio em Aluísio Azevedo que ora exclui um daqueles fatôres ora dá predomínio a outro.

Em $O$ cortiço, por exemplo, os personagens tornam-se irremediàvelmente impotentes, incapazes de reação contra as fôrças do meio, as quais os avassalam, porque são elas tão abafantes que esmagam completamente o indivíduo. Bem considerado, o romance apresenta não tipos ou personagens mas simplesmente uma massa amorfa, mistura degradante de vícios, crimes, de predomínio ostensivo do sexo, num estado de quase completa amoralidade, em que se avulta João Romão como figura de valor simbólico. Aluísio Azevedo deu tão excessiva importância à influência do meio sôbre o indivíduo, que tornou o último um verdadeiro títere e lhe negou tôda a capacidade ou mesmo possibilidade de reação que seria normalmente condicionada nos traços da herança biológica e da educação anteriormente recebida, e recebida em outro meio diverso, como é o caso dos personagens de $O$ cortiço. Tanto mais que o cortiço constituído como meio, resultado da agregação de indivíduos de camadas ou de procedências populares, foi produto do esfôrço, da determinação férrea, quase obstinada, da astúcia e da ambição de enriquecer e de subir socialmente de um único indivíduo - João Romão sôbre outros mais ou menos indiferentes, passivamente conformados.

O Cortiço é um excelente romance realista com pretensões naturalistas. $\mathbf{E}$ apesar dos exageros por um lado, e por outro dos defeitos de escola, é sem dúvida alguma ưma das melhores realizações do romance brasileiro daquela época.

Em face das observações rápidas e gerais que acabamos de fazer sôbre o romance de Alúísio Azevedo, somos levados a concluir que o-romancista, sem o estímulo do ambiente, sujeito às influências dos primeiros momentos de sua formação e sem dispor de material suficiente, nem tão pouco de tempo para colhê-lo, analisá-lo e estudá-lo, aceitando, por outro lado, como seria inevitável, os pro- 
cessos realistas-naturalistas, não podia deixar de realizar uma obra irregular, em parte negativa, em parte de grande valor social e de observação. E no último caso, predominantemente realista-naturalista, apesar das reminiscências românticas. Mas tanto no bom como no mau romance, sempre revelou notável talento de romancista.

\section{III. - Inglês de Souza}

E' sabido. que Inglês de Souza ficou consagrado em nossa literatura apenas com um de seus livros - $O$ missionário. $\mathbf{E}$ é romance que tem sido bastante valorizado pela crítica atual e que, na época em que surgiu, foi apontado por Araripe Junior como excelente e ao mesmo tempo a única realização naturalista de nossas letras. Aceitamos sem restrições a opinião de Araripe Junior: $O$ missionário é também para nós o único romance brasileiro que executou com equilíbrio e segurança os princípios e processos do naturalismo.

A tese desenvolvida na obra, o celibato religioso, já havia sido tratada por outros. Encontramos antecedentes no romantismo, como por exemplo em Bernardo Guimarães na literatura brasileira, e Alexandre Herculano na literatura portuguêsa; no realismo, apontamos Aluísio Azevedo entre nós, e Eça de Queiroz em Portugal. Dos romancistas brasileiros e portuguêses que estudaram o problema, parece-nos que o mais convincente é Inglês de Souza, dado o modo pelo qual o apresentou, bem como pelo significado humano e ao mesmo tempo social, embora em têrmos individuais e regionais, mas sem the sacrificar a universalidade. Contudo, no romance de Inglês de Souza a tese não se restringe ùnicamente ao celibato religioso, pois que a ela se associa o ideal de santidade, que por sua vez. implica no conceito mesmo de santidade.

Enunciados os têrmos do problema, deparamo-nos agora com o argumento e com o drama que êle encerra; o ambiente em que se desenrola o romance, surge naturalmente; e, relacionados os dois elementos básicos da obra, nada indica que o autor conduza os fatos para o desfêcho e conseqüentemente para uma conclusão intencional.

O personagem principal do romance, o Pe. Morais, é, à maneira do naturalismo, estudado desde a sua ascendência, infância, primeira educação, estudos no seminário e reeducação, até a idade adulta, quando se entrega, apenas sob o freio de suas aspirações, consciência e formação, aos imprevistos da vida.

O Pe. Morais, criado em plena natureza, observa da vida, inicialmente, mais o triunfo dos instintos criadores do que os ideais do espírito. $E^{\prime}$ natural que no decorrer da infância, sinta o despertar do instinto sexual, vagamente compreendido ou naturalmente aceito como simples e indispensável função da natureza geradora. Passa para o seminário e sofre uma transição brusca, atestada pela re- 
beldia inicial ou pelo desajustamento. Vê-se então sob os efeitos de uma reeducação pautada em disciplina rígida, visando principalmente a matar senão a adormecer aquelas primeiras e naturais manifestações do instinto sexual e até mesmo da inteligência, as quais deviam se revelar livremente. $O$ processo de reeducação é longo e termina surtindo, pelo menos aparentemente, os resultados desejados.

O Pe. Morais, ao mesmo tempo que é submetido a essa disciplina rígida e refreadora, entrega-se à leitura religiosa e não é de estranhar que seja arrastado pelo misticismo. Mas, apesar de tudo, não pode evitar os devaneios da vaidade que lhe é, por assim dizer, inata. $\mathbf{E}$ o seu misticismo que reflete uma coisa e outra, naturalmente se converte num meio de atingir a glória dos grandes mártires da Igreja. Nestas condições, deixa-se dominar por um falso conceito de santidade. $E^{\prime}$ falso, porque se resume, para o Pe. Morais, quase que ùnicamente na procura voluntária do martírio que lhe dará a glória de santo. E' certo que os grandes mártires que foram santos, nã̀o procuraram voluntàriamente o martírio; além do mais, surgiram num ambiente e época histórica que contribuiram para dar ao martírio um significado altamente cristão e, se atingiram a santida$\mathrm{de}$, não foi apenas por terem sido mártires. $\mathrm{E}$ ainda apontaríamos falsidade no conceito, se lembrássemos que os principais santos da Igreja o foram, entre outras coisas, porque souberam resistir, pelo comportamento e pela atitude espiritual, às tentações do vício e do pecado, depois de experimentá-los ou de conhecê-los comumente em periodo anterior à conversão. Podem objetar, o que é até certo ponto exato, que há no Pe. Morais, sob êste aspecto, uma tentativa de resistência, embora pouco convincente, pois diz respeito especificamente à castidade.

Com tais antecedentes um tanto falsos e secretamente vaidosos, - Pe. Morais sai do seminário para o exercício do sacerdócio. Procura, por vortade deliberada, uma pequena diocese e cai - talvez não o quisesse tanto assim - em ambiente mesquinho que logo o decepciona. Sentindo que era impossível chegar, na diocese escolhida, à concretização do seu ideal e que terminaria na penumbra do anonimato, entrega-se à aventura da catequese, vendo-se, por fôrça de suas leituras e de sua vaidade, à sombra dos grandes missionários.

Missionário torna-se o próprio Pe. Morais e sabe resistir heròicamente a um verdadeiro processo de tortura da natureza agreste, que enfrenta, até que, acidentalmente, enquanto se julga vítima de índios antropófagos, é conduzido por aborígenes catequizados a uma região mais ou menos paradisíaca, onde a natureza existe em tôda a sua exuberância criadora e acolhedora e onde, distante do convívio social, se encontra uma jovem mamaluca que lhe é oferecida com a mesma naturalidade com que um animal selvagem, na época do cio, se oferece a outro animal. Estamos, portanto, numa situação 
em que os instintos, sem nem siquer pressentir os freios controladores da moral ou da religião, se manifestam naturais, livres, espontâneos.

O Pe. Morais, ainda que convalescente, procura resistir ferozmente, tanto assim que é intenso o- conflito entre os instintos que despertam depois de longamente adormecidos, os efeitos da reeducação e o ideal religioso. E êle só se deixa vencer depois de uma luta dolorosa - e já era quase vitorioso - num momento irrefreável e inevitável de libertação sexual.

Passa então para uma nova situação que é o reverso do misticismo anterior, até que uma circunstância acidentalmente criada, apressa o seu regresso à paróquia de origem, mas levando consigo a mamaluca e sua família (índios catequizados). $\mathbf{E}$ ao chegar à cidadezinha de Silves, é recebido como herói e como mártir. Não resta dúvida que na atitude dos paroquianos e até mesmo dos inimigos do $\mathrm{Pe}$. Morais, os quais o glorificam, fica a caricatura do herói e mártir, não só religioso, à semelhança do próprio Pe.'Morais, mas também de muitos outros heróis, em outras épocas.

Como vimos, ao lado do desenvolvimento da tese do romance, observamos segura e equilibradamente a execução dos princípios fundamentais do naturalismo, apoiados na herança biológica, na educação, no meio e no momento. Estes fatôres, determinando ou condicionando o comportamento do indivíduo, atuam, repetimos, equilibradamente. $\mathrm{E}$ o equilíbrio consiste não só no modo plástico pelo qual se evidenciam as influências dos fatôres citados, mas também na conformidade do comportamento dos personagens à verdade moral. Ao demais, não há uma passagem em que o autor desça à maneira sistemática do realismo e de muitos naturalistas, ao excessivo pormenor, minúcias nas descrições e na narração, ao gôsto de fixar a degradação e corrupção principalmente das relações sexuais. Finalmente, além de tantas outras qualidades de descricionista, de narrador, de fixador de costumes e de tipos, Inglês de Souza soube impregnar o seu romance de uma feição acentuadamente regional no que concerne à paiságem social e da natureza, sem lhe sacrificar a universalidade dramática.

\section{IV. - Rodolfo Teófilo e Domingos Olimpio.}

Além de Machado de Assis, Aluísio Azevedo, Inglês de Souza e Raul Pompéia os quais são os mais expressivos representantes do romance brasileiro da segunda metade de século XIX, há outros nomes que tanto pela aceitação do público como pela crítica são considerados como figuras secundárias. Por exemplo: Rodolfo Teófilo. Domingos Olímpio e Adolfo Caminha. Quanto a Graça Aranha e Lima Barreto, aliás romancistas de grande valor, não resta đúvida que são figuras que devem ser ligadas ao romance modernista, na qualidade de precursores; nas mesmas condições, já o dissemos, colocamos Raul Pompéia. 
Se os três nomes apontados como secundários realmente o são, não deixam de apresentar, contudo, grande importância na evolução do romance brasileiro, principalmente no que diz respeito à temática. De fato, Rodolfo Teófilo e Domingos Olímpio são afirmadores em nossa ficção do que podemos chamar "ciclo da sêca e do cangaço". Trata-se do aproveitamento, como temas da ficção, das conseqüências sociais e dos aspectos humanos do problema do cangaço aliado ao misticismo e ao fenômeno das sêcas no nordeste brasileira Podemos mesmo dizer, de modo restrito, ao Ceará. E de tal forma êsses temas foram desenvolvidos, cultivados, que formaram, conforme escrevemos, o "ciclo da sêca e do cangaço" no romance brasileiro, ao mesmo tempo traço fundamental do regionalismo dos escritores do nordeste.

Na ficção romântica, encontramos alguns antecedentes temáticos, representados pàlidamente por José de Alencar em $O$ sertanejo e de modo mais definido em $O$ Cabeleira de Franklin Távora, típico romancista de transição do romantismo para o realismo, ligado à chamada "Escola do Recife". Mas, repetimos, a afirmação plena do ciclo regionalista indicado, rico de material sociológico, tanto assim que de grande interêsse subsidiário para o estudo de certos aspectos sociais do nordeste, só se verificou com Rodolfo Teófilo e Domingos Olímpio.

Rodolfo Teófilo apresenta-se mais completo do que Domingos Olímpio. E', sobretudo, mais minucioso e mais bem documentado. $E_{m}$ três dos seus romances, os principais - $A$ fome, Os Brilhantes e $O$ paroara - focaliza os principais aspectos do cangaço, do misticismo e das conseqüências das sêcas, todos intimamente relacionados.

Em $A$ fome, vemos o panorama desolador da sêca, na região do Ceará, com as suas principais consequiências sociais, econômicas 'e morais. Vão desde a desvalorização quase total da propriedade agrícola e de outros bens, até o abandôno de tudo, quando a transumância, primeiro, porque depois vem a emigração, se torna inevitável para grande parte da população. E com a transumância, verifica-se a concentração em alguns centros mais favorecidos, nos quais, então, de ordinário predomina a promiscuidade, a ausência quase completa de noção moral e de valores sociais.

Em Os Brilhantes, o romancista ainda se restringe ao Ceará. Estuda principalmente o impressionante fenômeno do banditismo que, no nordeste, podemos caracterizar sob três aspectos. Primeiro, o banditismo simplesmente assaltante, corruptor e baixamente criminoso. Segundo, o banditismo que, se nos permitem, diríamos de "boa indole", porque visa essencialmente à vingança da injustiça cometida pela própria justiça e que chega mesmo a proteger populações ou famílias indefesas, quando assaltadas pelos bandidos do primeiro tipo, da mesma forma que contra as arbitrariedades das autoridades e dos poderosos. Finalmente, o banditismo fanático que de ordi- 
nário se confunde com os anteriores e que resulta em agrupamentos à semelhança do de Canudos, nos quais vemos o jagunço fazendo promessas aos santos de sua devoção, invocando sucesso nos assaltos e crimes, para logo, uma vez perpetrados, thes oferecer o punhal ensanguentado. Em Os Brilhantes, Rodolfo Teófilo dá-nos uma idéia quase geral do banditismo nordestino, particularmente no seu segundo aspecto associado ao fenômeno da sêca, escrevendo a história de um bandido que ficou na tradição - Jesuíno Brilhantes.

Em $O$ Paroara, vemos a consequiência última da sêca, que resulta na emigração das populações vitimadas e sem recursos, para outros estados.

Rodolfu Teófilo pôde realizar um romance de valor documental, porque foi grande conhecedor da região nordestina, além de ter sido uma figura de notáveis qualidades humanas. Em momentos de calamidade, revelando extraordinária abnegação e coragem, ia levar recursos aos necessitados e transmitir noções de higiene às populações assoladas pela sêca. Além de romances, deixou mesmo estudos de valor científico sôbre sêcas e epidemias do nordeste.

Domingos Olímpio, autor de Luzia-Homem, romance de apreciáveis qualidades, desenvolve temas semelhantes aos de Rodolfo Teófilo - a sêca e o cangaço associados. Se é menos preciso e minucioso do que Rodolfo Teófilo que deixou obra mais numerosa, é, contudo, verdadeiramente poeta em muitas passagens do romance que escreveu com equilíbrio, grandes qualidades de descricionista e de narrador.

A afirmação do "ciclo da sêca e do cangaço", na literatura pròpriamente sociológica, teve apôio, sem dúvida alguma, nos dois ficcionistas indicados. E vem a propósito lembrar o nome de Afonso Arinos, autor de $O$ s jagunços, e de Manuel Benício que escreveu $O$ rei dos jagunços, obras que, antes de Euclides da Cunha estudar cientificamente o fenômeno de Canudos, o apresentam como assunto de romance e de crônica. Posteriormente, isto é, já com os modernistas, continuamos a observar a freqüência do "ciclo da sêca e do cangaço" no romance brasileiro. O melhor exemplo é $O$ quinze de Raquel de Queiroz, além de outros. E de forma diluída, sem a predominância com que aparece nos romancista indicados, vêmo-lo ainda em escritores como José Lins do Rêgo e Graciliano Ramos.

$$
\text { V. - Conclusão. }
$$

O romance da época realista continua, como é natural, certos aspectos básicos da tradição do gênero, lançados pelo romantismo. Assim afirma, como tendências anteriores, o regionalismo e o romance citadino; abandona, até certo ponto, outras tendências já iniciadas: o romance histórico que, embora pàlidamente, ressurge depois, da mesma forma que o indianismo que, como sabemos, foi objeto de revisão por parte de alguns modernistas. Cria tendências novas e com 
elas amplia os horizontes de nossa ficção. Tratam-se, no caso, do psicologismo e do intelectualismo que oferecem os primeiros elementos mais apreciáveis, depois da contribuição de Alencar, da universalização do romance brasileiro.

O regionalismo, assim como o romance citadino, ganha, com o realismo-naturalismo, mais precisão, mais valor documental e social do que na época anterior. O motivo da valorização resulta sem dúvida alguma da objetividade, do estudo direto da realidade e dos aspectos sociais regionalistas, os quais o romancista transporta para a sua obra. Das sugestões vagas de Alencar, da maior preocupação social de Franklin Távora, sem considerar outros regionalistas românticos, chegamos à afirmação plena de substância documental dos regionalistas realistas. Realmente, Rodolfo Teófilo e Domingos Olímpio definem o "ciclo da sêca e do cangaço" e sugerem o nordeste místico; um escritor do centro, Afonso Arinos, além de Manuel Benício, completa êsse esfôrço de observação, que eclode na obra de Euclides da Cunha. Inglês de Souza amplia o campo de informações, revelando o extremo norte.

Nestas condições, quando surgem os modernos romancistas brasileiros do nordeste - José Lins do Rêgo, Raquel de Queiroz, Jorge Amado, José Américo de Almeida, Graciliano Ramos - já contávamos com uma temática rica, complexa, característica, perfeitamente definida, à qual, por fôrça da tradição, êles se filiaram, enriquecendo-a, ao mesmo tempo, de novas contribuições.

Como criadores de tendências novas, há Machado de Assis e, de modo destacado, dois precursores: Raul Pompéia e Graça Aranha; o primeiro, Machado de Assis, cria o romance psicológico; o segundo, apesar do aparente anacronismo, já escreve o romance caracterìsticamente analítico e decalcado cem por cento sôbre a experiência pessoal; Graça Aranha, não obstante ser maranhense, espalha as sementes do romance modernista do sul, apontando o imigrante como assunto literário de primeira ordem e como um problema nacional dos mais importantes, o que, é preciso reconhecer, Aluísio Azevedo vagamente havia sugerido em $O$ cortiço e José de Alencar em seus romances citadinos (v. o prefácio de Sonhos d'ouro). Além dos aspectos particulares indicados, êles inauguram na ficção brasileira a preocupação cultural, o intelectualismo. Como se sabe, tudo isto foi retomado e ampliado pelo modernismo.

Resta verificar agora até que ponto o romance em questão se filia às tendências realistas e naturalistas. Não devemos fazer aqui a exposição dessas duas escolas literắrias que se desenvolveram paralelamente e que para alguns críticos se confundem. A verdade é que o realismo se distingue do naturalismo, ou vice-versa, apesar de o último não ser outra coisa senão, conforme já se escreveu, o "realismo especializado". Mas é nessa especialização que reside a diferença e, para tanto, Zola elaborou uma teoria de romance, que observou religiosamente. Não obstante ter contado com muitos dis- 
cípulos, nem todos tiveram a paciência, a extraordinária capacidade de trabalho, o equilíbrio e o total respeito devotado à doutrina, demonstrados pelo mesmo Zola. Resultado: houve a simplificação por um lado, o exagêro pelo outro, e do desequilíbrio resultou um realismo meio especializado, o que podemos chamar de realismo-naturalismo. E foi o que se verificou no Brasil, com exceção de $O$ missionário de Inglês de Souza, o único romance nosso que resiste à análise à luz da doutrina preconizada por Emílio Zola .

Reconsiderando algumas das observações feitas, achamos que Machado de Assis, colocado em posição destacada, teve uma orientação própria; no conjunto da obra que escreveu, sua atitude estética representa um esfôrço de equilíbrio e coerência em face de tôda a herança cultural que the foi transmitida.

Aluísio Azevedo às vêzes se aproximou do naturalismo, mas nunca se libertou das reminiscências românticas, além de outros desequilíbrios.

Júlio Ribeiro, não obstante sua arrogante pretensão, não realizou senão uma obra puramente cerebral $-A$ carne, cujo valor consiste apenas nas qualidades de escritor, as quais ela denota. Nessa situação de exagêro e de desequilíbrio, também está Adolfo Caminha que, além de $\boldsymbol{A}$ normalista, tentou um arrojado estudo de patologia sexual, escrevendo $O$ bom crioulo. listas.

Rodolfo Teófilo e Domingos Olímpio são pròpriamente rea- 